\title{
Penerapan Metode Bermain Peran Untuk Meningkatkan Perilaku Sopan Santun Pada Siswa Sekolah Dasar
}

\section{Application Of Role Play Methods To Improve Polite Behaviors In Elementary School Students}

\author{
Cristine Roselvia Tri Amelia* \\ Fakultas Psikologi, Universitas Semarang, Indonesia
}

Disubmit: 24 Juni 2021; Diproses: 27 Juni 2021; Diaccept: 27 Juli 2021; Dipublish:02 Agustus 2021

*Corresponding author: E-mail: cristine@usm.ac.id

\begin{abstract}
Abstrak
Penelitian ini bertujuan untuk meningkatan perilaku sopan santun pada siswa kelas 1 SD melalui metode bermain peran. Hipotesis yang dikemukakan dalam penelitian ini adalah adanya peningkatan perilaku sopan santun pada siswa sekolah dasar dengan menggunakan metode bermain peran. Metode penelitian yang digunakan di dalam penelitian ini adalah metode experimen dengan desain pretest dan post test satu kelompok. Penelitian ini dilakukan di Semarang dengan subjek yaitu 5 anak kelas 1 SD X di Semarang. Dalam pengumpulan data, peneliti menggunakan observasi. Observasi dilaksanakan selama dua tahap yaitu sebelum pemberian intervensi dan setelah pemberian intervensi, dimana setiap tahap observasi terdiri dari empat kali pertemuan. Pada tahap observasi pertama diperoleh hasil bahwa terdapat 1 orang yang menunjukkan perilaku sopan dan 4 orang menunjukkan perilaku kurang sopan. Tahap observasi kedua diperoleh hasil bahwa 5 orang siswa menunjukkan perilaku sopan. Analisa data uji beda dengan menggunakan t-test, diketahui nilai sig (2-tailed) sebesar $\mathrm{p}=0,000$, artinya ada perbedaan yang signifikan antara sebelum diberi perlakuan dan sesudah diberi perlakuan. Hasil analisa data juga menunjukkan bahwa terjadi peningkatan perilaku sopan santun pada siswa kelas 1 SD menggunakan metode bermain peran dengan skor sebesar 13,45.
\end{abstract}

Kata Kunci: Bermain Peran; Sopan Santun

\begin{abstract}
This study aims to improve polite behavior in grade 1 elementary school students through the role play method. The hypothesis put forward in this study is an increase in polite behavior in elementary school students by using the role play method. The research method used in this study was an experimental method with one group pretest and posttest design. This research was conducted in Semarang with the subject, namely 5 grade 1 children of SD X in Semarang. In collecting data, researchers used observation. Observations were carried out for two steps, where each observation step consisted of four meetings. In step 1, it was found that there was 1 person who showed polite behavior and 4 people showed disrespectful behavior. In the second step, the results showed that 5 students showed polite behavior. Analysis of different test data using $t$-test, it is known that the sig (2-tailed) value of $p=0.000$ means that there is a significant difference between before being treated and after being given treatment. The results of the data analysis also showed that there was increasing polite behavior in grade 1 elementary school students by using the role-play method with a score of 13.45.
\end{abstract}

Keywords: Polite ; Role Play

DOI: https://doi.org/10.51849/j-p3k.v2i2.108

\section{Rekomendasi mensitasi :}

Amelia, C.R.T. (2021), Penerapan Metode Bermain Peran Untuk Meningkatkan Perilaku Sopan Santun Pada Siswa Sekolah Dasar. Jurnal Penelitian Pendidikan, Psikologi dan Kesehatan (J-P3K), 2 (2): 126-134. 


\section{PENDAHULUAN}

Sikap sopan santun merupakan salah satu warisan budaya leluhur kita, oleh karena itu sangat penting untuk menanamkan kebiasaan sopan santun kepada anak. Sopan santun merupakan perilaku atau perbuatan untuk menghormati dan menghargai orang lain (Suryani, 2017). Dewasa ini, sikap sopan santun seringkali diabaikan oleh sebagian orang termasuk juga anak - anak. Berdasarkan wawancara awal dengan Kepala Sekolah Dasar X di Semarang, banyak siswa yang tidak mengerti sopan santun dalam pergaulan di lingkungan sekolah.

Ada 5 orang guru yang mengeluhkan dengan kurangnya sikap sopan santun siswa, terlebih siswa kelas 1. Perilaku kurang sopan tersebut ditunjukkan yaitu pada saat berbicara dengan guru, siswa menggunakan bahasa seperti berbicara dengan temannya, dan ketika bertemu guru hanya lewat saja tidak menunjukan etika sopan santun ketika bertemu dengan seorang guru. Kondisi seperti ini, pada akhirnya menghambat proses interaksi di dalam kelas, karena pada setiap pembelajaran perhatian pendidik hanya terfokus pada anak yang kurang sopan tersebut.

Berdasarkan hasil observasi peneliti di SD X ditemukan indikasi bahwa perilaku sopan santun siswa masih rendah. Terbukti dari 5 siswa dan siswi yang berada di kelas 1, kelima siswa menunjukkan indikasi-indikasi perilaku kurang sopan di antaranya anak berbicara kurang sopan seperti membentak guru, berteriak, menggunakan bahasa kasar, beberapa anak masuk ke ruang kelas tanpa mengucapkan salam, tidak menghargai teman, menyela pembicaraan guru, membantah atau pun mengejek saat guru meminta anak - anak untuk duduk tenang, kaki naik ke atas kursi saat ada guru di kelas.

Berdasarkan wawancara kepada kepala sekolah, kepala sekolah mengungkapkan hal yang sama yaitu perilaku siswa kelas I sering dianggap "nakal" karena hampir semua siswa berbicara kasar baik antar teman, seringkali melakukan permainan secara fisik yang berlebihan, misalnya: mendorong, memukul, mencubit, menarik tangan dan kaki. Siswa kelas I juga dianggap sangat membangkang dengan guru, hal ini terlihat dari bagaimana murid menjawab dengan seenaknya, tanpa ada sopan santun dengan guru, bahkan tertawa pada saat guru menegur atau memarahi siswa.

Dalam mengikuti pelajaran di sekolah, siswa hanya bisa duduk tenang dalam durasi 15 menit setelah itu muridmurid akan berdiri, berbicara berlebihan, saling berteriak, bahkan berjalan mengitari kelas. Pada awalnya hanya dua orang siswa yang dianggap mengganggu ketertiban kelas, namun saat ini seluruh siswa kelas I berperilaku yang sama. Guru telah menerapkan berbagai metode untuk dapat mengendalikan perilaku siswa antara lain menggunakan reward dan punishment. Namun cara tersebut, belum berhasil untuk meningkatkan perilaku sopan santun siswa.

Perilaku sopan santun sangat penting diajarkan kepada anak sejak dini. Sopan santun dapat membuat anak menjadi memahami apa yang boleh dan tidak boleh dilakukan (Melati, 2012). Perilaku sopan santun termasuk hal yang 
penting dalam bersosialisasi dengan orang lain karena dengan seseorang bersikap sopan, ia dapat dihargai dan disenangi dimana pun ia berada (Damayanti et al., 2018).

Sopan santun merupakan aturan dalam masyarakat yang secara turun temurun dapat memberikan manfaat untuk menjalin pergaulan yang akrab dengan sesama manusia, saling mengerti dan saling menghormati (Yulianti et al., 2018). Beberapa indikator yang mencerminkan perilaku sopan santun yaitu menghormati orang yang lebih tua, menggunakan tangan kanan ketika menerima sesuatu, berkata yang baik (tidak kasar), tidak meludah di sembarang tempat, ketika berjumpa dengan guru memberikan salam, dan juga menghargai jika terjadi perbedaan pendapat dengan orang lain (Wahyudi \& Arsana, 2014).

Sopan santun menjadi bagian yang penting karena dengan seseorang memiliki perilaku sopan santun, ia dapat diterima di lingkungan sosialnya (Masruroh et al., 2020). Bermain peran merupakan cara pembelajaran yang menyenangkan bagi anak karena dengan bermain peran seorang anak dapat bermain, mengembangkan imajinasinya, dan memerankan seperti tokoh atau benda yang ada pada cerita tersebut (Sofia dalam Elisa \& Hazizah, 2019).

Penerapan bermain peran di kelas dapat membantu anak menjadi lebih aktif dalam kegiatan pembelajaran karena dengan bermain peran, anak dapat merasakan langsung menjadi seorang tokoh yang ada dalam cerita (Masruroh et al., 2020).

Dalam pelaksanaan penelitian ini, peneliti dan juga guru mengarahkan siswa untuk melakukan perannya yang menggambarkan perilaku sopan santun. Metode bermain peran yang dilakukan, mendorong anak untuk memerankan perannya sesuai tema yang telah disiapkan oleh guru. Guru bertindak sebagai pengarah atau fasilitator agar anak mampu mencerminkan perilaku yang diinginkan.

Dengan bermain peran dapat membantu anak untuk mengetahui apa yang dirasakan orang lain, dapat berpikir tindakan yang dilakukan dan memahami konsekuensi dari perilaku mereka (Seefeldt et al., 2010). Penelitian penelitian terdahulu menunjukkan bahwa metode bermain peran efektif untuk meningkatkan sopan santun pada anak di antaranya yaitu penelitian yang pernah dilakukan oleh (Tomayahu, 2013), pada penelitian tersebut didapatkan hasil bahwa metode bermain peran atau role play efektif untuk meningkatkan pemahaman siswa terhadap perilaku sopan santun siswa kelas VII di MTs AlHuda Kota Gorontalo,

Hal yang serupa juga diungkapkan oleh (Aini, 2019) dalam penelitiannya yang berjudul Pengembangan Karakter Sopan Santun melalui Kegiatan Bermain Peran Pada Anak Usia Dini di TK Adirasa Jumiang, dalam penelitiannya didapatkan hasil bahwa melalui kegiatan bermain peran dapat mengembangkan karakter sopan santun. Penelitian lain juga dilakukan (Hasanah, 2018) yang berjudul Peningkatan Karakter Sopan Santun melalui Kegiatan Bermain Peran (Role Playing) pada Anak Kelompok B1 di KB/TK An-Nur Malang, menunjukkan hasil bahwa penerapan kegiatan bermain peran (role playing) dapat meningkatkan karakter 
sopan santun anak kelompok B1 di KB/TK An-Nur Malang.

Penelitian yang dilakukan oleh (Vizeshfar et al., 2016), mengungkapkan bahwa metode bermain peran merupakan metode yang efektif untuk pendidikan dan pengajaran, karena dapat meningkatkan etika atau moral serta kerja sama seseorang. Berdasarkan permasalahan tersebut, penelitian ini bertujuan untuk mengukur keefektifan metode bermain peran untuk meningkatkan perilaku sopan santun pada siswa Sekolah Dasar.

\section{METODE PENELITIAN}

Penelitian ini menggunakan metode eksperimen. Desain penelitian yang digunakan adalah desain A-B-A. Desain AB-A seperti digambarkan pada di bawah ini (Saifuddin, 2019) :

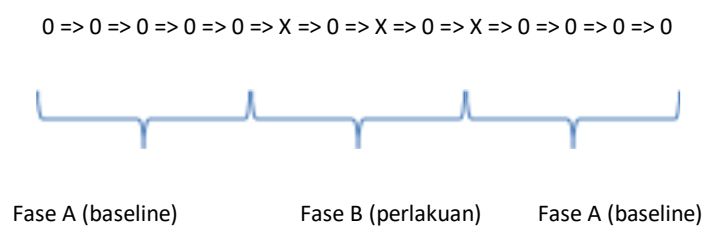

Gambar 1. Desain A-B-A

Bermain peran adalah sebuah metode atau teknik dimana seseorang dapat bermain, mengembangkan imajinasinya, dan memerankan seperti tokoh atau benda yang ada pada cerita tersebut.

Sopan santun merupakan aturan dalam masyarakat yang secara turun temurun dapat memberikan manfaat untuk menjalin pergaulan yang akrab dengan sesama manusia, saling mengerti dan saling menghormati.

Penelitian ini dilakukan di Sekolah Dasar X di kota Semarang. Peneliti mengumpulkan data yang ada di lapangan, dengan menggunakan wawancara, observasi, dan dokumentasi. Wawancara dilakukan kepada guru yang mengajar siswa kelas 1 beserta kepala sekolah untuk mencari informasi mengenai perilaku sopan santun siswa kelas 1 di SD $\mathrm{X}$ kota Semarang, sedangkan observasi dilakukan untuk mengetahui perilaku sopan santun anak dan melihat bagaimana cara guru dalam mengajarkan sopan santun pada siswa.

Dalam melakukan observasi, peneliti didampingi oleh satu orang rekan sejawat yang bertindak sebagai observer penelitian. Dalam penelitian ini akan digunakan instrument pemantauan berupa lembaran observasi yaitu berupa checklist kemunculan perilaku, dimana observer akan menghitung frekuensi kemunculan dari perilaku yang akan diobservasi. Indikator yang diobservasi melalui lembaran observasi yaitu : menyapa orang lain dengan cara yang sopan, meminta ijin kepada guru saat keluar kelas, tidak menyela saat orang lain berbicara.

Observasi dilaksanakan selama 2 tahap yaitu sebelum pemberian intervensi dan setelah pemberian intervensi, dimana setiap tahap observasi terdiri dari $4 \mathrm{x}$ pertemuan. Validitas yang digunakan adalah validitas isi. Validitas isi digunakan untuk memastikan bahwa sekumpulan item yang dimasukkan di dalam pengukuran mewakili konsep yang akan diukur (Hendryadi, 2017). Subjek penelitian yaitu siswa kelas 1 SD X di kota Semarang yang berjumlah 5 orang. Dalam penelitian ini dilakukan pengukuran metode bermain peran yang dapat digunakan untuk meningkatkan perilaku 
sopan santun. Pengolahan data dilakukan dengan menggunakan uji beda T- Test.

\section{HASIL DAN PEMBAHASAN}

Tabel 1. Independent Samples Test

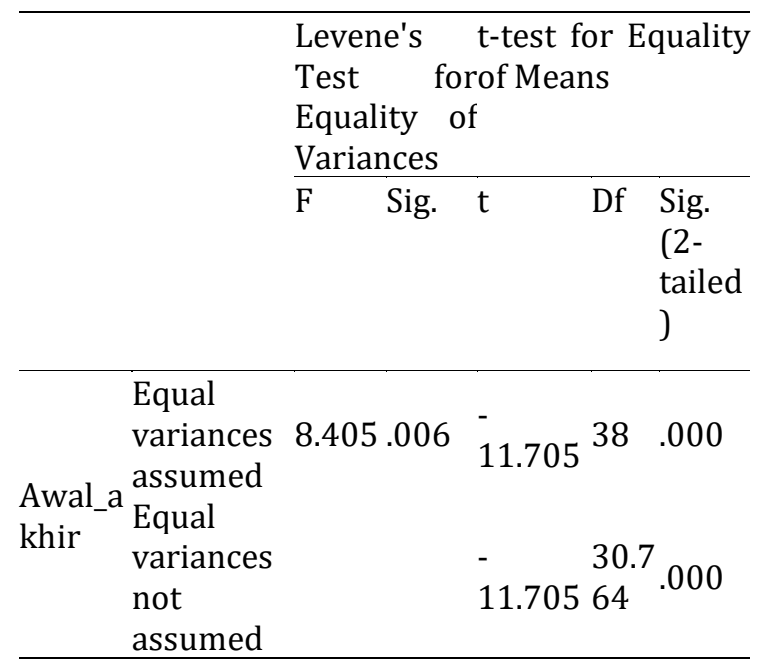

Hasil analisis uji beda dengan menggunakan t-test, dari tabel 1 yaitu tabel Independent Samples Test pada kolom Equal variances assumed diketahui nilai sig (2-tailed) sebesar $\mathrm{p}=0,000$ artinya ada perbedaan yang signifikan antara sebelum diberi perlakuan dan sesudah diberi perlakuan.

Tabel 2. Hasil Baseline Awal dan Baseline Akhir

\begin{tabular}{llll}
\hline & Kelompok & $\mathrm{N}$ & Mean \\
\hline $\begin{array}{l}\text { Baseline } \\
\text { Awal_ }\end{array}$ & Baseline & 20 & 5.35 \\
$\begin{array}{l}\text { Baseline } \\
\text { Akhir }\end{array}$ & Awal & & \\
& $\begin{array}{l}\text { Baseline } \\
\text { Akhir }\end{array}$ & 20 & 18.80 \\
& & & \\
& & &
\end{tabular}

Tabel 2 juga menunjukkan bahwa terjadi peningkatan perilaku sopan santun pada siswa kelas 1 SD dengan skor sebesar 13,45 . Nilai baseline awal yang semula memiliki rata-rata 5.35 menjadi 18.80 pada perhitungan baseline akhir, yang menunjukkan adanya peningkatan perilaku sopan santun siswa dengan menggunakan metode bermain peran.

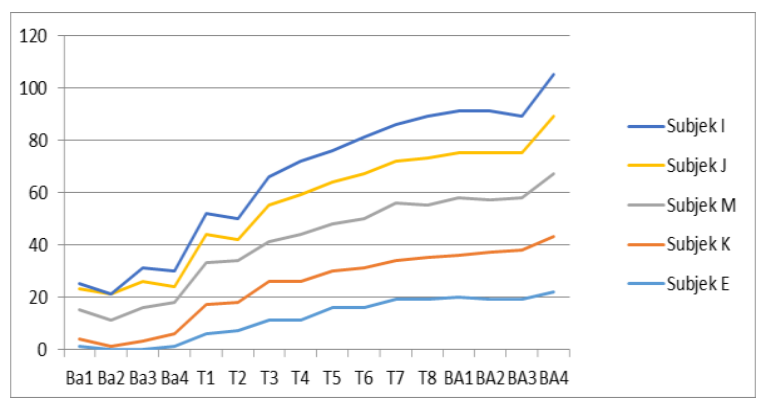

Grafik 1. Grafik peningkatan perilaku sopan santun pada kelima subjek

Perilaku sopan santun pada siswa dalam kegiatan bermain peran dapat dilihat juga pada grafik 1 dimana kurva pada grafik 1 menunjukkan kurva yang naik yang berarti bahwa terjadinya peningkatan perilaku kelima siswa mulai dari setelah diberikan intervensi yaitu bermain peran sampai dengan setelah diberikan intervensi.

Berdasarkan data yang telah disajikan diatas, pada tahap 1 (sebelum pemberian intervensi atau baseline awal) diperoleh hasil bahwa terdapat 1 orang yang menunjukkan perilaku sopan dan 4 orang menunjukkan perilaku kurang sopan. Sementara pada tahap 2 (setelah pemberian intervensi atau baseline akhir) terjadi peningkatan perilaku sopan santun dimana ke 5 anak menunjukkan perilaku sopan santun.

Perilaku sopan santun siswa meningkat setelah peneliti dan guru yang mempunyai peran sebagai fasilitator menerapkan metode bermain peran di dalam pembelajaran. Guru sebagai pendidik di sekolah harus bisa mengarahkan siswa kepada hal yang positif bagi siswa, seperti pengajaran sopan santun. Pengajaran sopan santun 
sebaiknya di mulai dari sejak dini, agar anak menjadi lebih mudah untuk bersosialisasi dengan orang yang ada di lingkungannya. Tentunya mengajarkan sopan santun membutuhkan proses yang panjang dan harus terus diajarkan secara konsisten agar mendapatkan hasil yang maksimal (Handayani, 2013).

Bermain peran merupakan cara yang efektif yang dapat digunakan untuk meningkatkan perilaku sopan santun pada anak. Hal ini diungkapkan oleh Hasanah (2018) dalam penelitiannya yang berjudul Peningkatan Karakter Sopan Santun melalui Kegiatan Bermain Peran (Role Playing) pada Anak Kelompok B1 di KB/TK An-Nur Malang, menunjukkan hasil bahwa penerapan kegiatan bermain peran (role playing) dapat meningkatkan karakter sopan santun anak kelompok B1 di KB/TK An-Nur Malang.

Bermain peran merupakan metode yang menyenangkan bagi siswa karena dengan melakukan perannya, siswa merasa seperti bermain (Handayani, 2013). Hal ini sesuai pendapat yang diungkapkan oleh Garvey (Azizah, 2013) bahwa anak - anak sangat menyukai bermain peran. Bermain peran merupakan metode pengajaran yang aktif dimana siswa diminta untuk melakukan peran tertentu melalui perkataan, melakukan dan berbagi (Altun, 2015).

Bermain peran dapat membantu siswa untuk lebih mengungkapkan atau mengeskpresikan perasaannya, sehingga bisa menentukan sikap, nilai, keyakinan (belief) yang tepat dengan bantuan kelompok (Datau, 2013). Hal ini sejalan dengan penelitian yang telah dilakukan oleh (Tomayahu, 2013) yang membuktikan bahwa metode bermain peran dalam layanan bimbingan kelompok dapat meningkatkan perilaku sopan santun siswa.

Selama proses pelaksanaan bermain peran, terlihat bahwa pelatihan bermain peran dapat meningkatkan perilaku sopan santun pada siswa. Pada saat sesi bermain peran berlangsung yaitu dengan tema menyapa dengan cara yang sopan, menghargai saat guru dan teman berbicara, meminta ijin saat keluar kelas. Setiap siswa memperagakan tokohnya. Saat memperagakan, siswa terlihat menghayati perannya masing-masing. Siswa pun tampak saling bekerja sama ketika bermain peran.

Setelah sesi bermain peran selesai, masing - masing siswa diminta untuk menceritakan bagaimana perannya, apa yang salah di dalam cerita dan sikap apa yang harus dilakukan. Aspek sopan santun siswa terlihat meningkat seperti siswa tampak lebih sopan dengan guru yaitu ketika ada guru pelajaran lain masuk, siswa langsung menghampiri guru tersebut dan mencium tangan lalu mengucapkan salam kepada guru. Ketika ada 1 siswa yang lupa, teman - temannya mengingatkan untuk menyapa guru yang masuk, kemudian ketika berbicara dengan teman atau guru pun lembut, tidak membentak dan tidak berbicara kasar.

Perilaku lain yang muncul yaitu ketika guru sedang menerangkan pelajaran, siswa memperhatikan guru yang sedang mengajar, 4 orang siswa mendengarkan guru dan tidak menyela pembicaraan guru namun 1 orang siswa masih ada yang menyela pembicaran guru. Selain itu perilaku sopan santun yang tampak pada siswa yaitu meminta ijin kepada guru atau mengatakan kepada 
guru jika ingin ke kamar mandi pada saat pelajaran berlangsung, bahkan salah satu siswa mengatakan bahwa ketika akan keluar kelas misalnya ke kamar mandi sebaiknya mendekati guru dan meminta ijin untuk ke kamar mandi kepada bu guru.

Dengan demikian dapat disimpulkan bahwa perilaku sopan santun siswa dapat meningkat dengan menggunakan metode bermain peran. Hal ini sesuai dengan penelitian sebelumnya yang pernah dilakukan oleh Faridah et al (2016) dengan judul Peningkatan Perilaku Sopan Santun Pada Anak Usia 5-6 Tahun di Taman Kanak - Kanak PGRI Ketapang. Perilaku-perilaku sopan santun mulai dibiasakan siswa dalam kehidupan sehariharinya terutama di sekolah. Guru sebagai pendidik di sekolah harus selalu memberi arahan dan mengingatkan anak-anak terutama dalam berperilaku yang sopan dan santun.

Mengajarkan serta mengembangkan perilaku sopan santun terutama pada anak dapat dilakukan menggunakan metode belajar dengan cara bermain secara bertahap (Faridah et al., 2016). Pada umumnya anak - anak menyukai bermain. Hal ini sesuai dengan yang diungkapkan oleh Yus (2011) yang menyatakan bahwa bermain merupakan sesuatu yang menyenangkan bagi anak karena dengan bermain, anak akan bebas dan tidak ada paksaaan untuk melakukan apapun dalam permainan yang dilakukannya.

Dalam pelatihan bermain peran ini, para siswa kelas 1 Sekolah $\mathrm{X}$ di Kota Semarang diajak untuk memainkan perannya dalam sebuah percakapan dengan tema yang telah dipilih, pada perannya tersebut para siswa diajak untuk mengeksplorasi bagaimana perasaannya, bagaimana harus bersikap, dan strategi pemecahan masalah dengan cara memperagakan secara bersamasama. Saat memainkan perannya, setiap siswa kelas 1 SD X dapat merasakan perannya di dalam bermain, mengerti perasaan orang lain yang memerankan tokoh yang lain, dan nilai - nilai yang mendasari berperilaku sopan santun terhadap teman dan juga gurunya.

Setelah para siswa selesai memainkan perannya, para siswa diajak oleh peneliti dan juga guru berdiskusi mengenai perannya masing - masing dan peran orang lain. Hal ini sesuai pendapat yang diungkapkan oleh (Halifah, 2020) dengan bermain peran seseorang dapat memahami perannya dan juga peran yang dimainkan oleh orang lain.

Setiap proses bermain peran, setiap pemeranannya dapat membangun kemampuan sosial dan simpati anak. Saat anak memainkan perannya, anak sedang menempatkan dirinya pada pengalaman yang dirasakan oleh orang lain sehingga dapat membantu anak untuk mengembangkan rasa empatinya (Vebriani, 2019). Hal ini sesuai pendapat yang diungkapkan oleh (Damayanti et al., 2018) yang menyatakan bahwa dengan bermain peran, seseorang dapat memahami apa yang sedang diperankannya dan yang dimainkan oleh orang lain sehingga ia akan mengerti perasaan, sikap, dan nilai-nilai yang didasarinya.

Pendapat yang serupa juga diungkapkan oleh Hani (2014) dengan bermain peran, siswa dihadapkan pada situasi tertentu dan diminta untuk 
memainkan suatu peran secara langsung sehingga ketika dalam kehidupan sehari hari siswa dihadapkan dalam situasi yang sama dalam kehidupan nyata maka siswa akan mengingat ketika memainkan peran yang dilakukan dan mengetahui apa yang harus dilakukan.

Dengan meningkatnya perilaku sopan santun siswa di SD X, diharapkan metode bermain peran ini dapat diajarkan kepada siswa secara rutin supaya siswa dapat lebih memahami situasi sosial yang ada di sekitarnya termasuk di antaranya perilaku sopan santun kepada orang lain.

\section{SIMPULAN}

Hasil penelitian menunjukkan bahwa, ada perbedaan yang signifikan antara sebelum diberi perlakuan dan sesudah diberi perlakuan, yang berarti bahwa terjadi peningkatan perilaku sopan santun pada siswa kelas 1 SD X di kota Semarang setelah diberikan perlakuan dengan menggunakan metode bermain peran seperti di antaranya yaitu siswa mengucapkan salam ketika bertemu guru dan mencium tangan guru, ketika memanggil guru atau teman sudah dengan cara yang sopan dan tidak berteriak, siswa bisa meminta ijin terlebih dahulu kepada guru jika akan keluar kelas.

Berdasarkan hasil penelitian yang telah dilaksanakan maka dapatlah disarankan agar metode bermain peran sebaiknya tetap digunakan sebagai program bulanan untuk menanamkan nilai sopan santun pada siswa.

\section{DAFTAR PUSTAKA}

Aini, Q. (2019). Pengembangan Karakter Sopan Santun Melalui Kegiatan Bermain Peran
Pada Anak Usia Dini Di Tk Adirasa Jumiang. Islamic EduKids, 1(2), 41-48.

Altun, M. (2015). Using Role-Play Activities To Develop Speaking Skills: A Case Study In The Language Classroom. 1(4), 354-363.

Azizah, N. (2013). Tingkat Ketrampilan Berbicara Ditinjau Dari Metode Bermain Peran Pada Anak Usia 5-6 Tahun. Skripsi. Fakultas Ilmu Pendidikan. Universitas Negeri Semarang.

Damayanti, R. R., CH, M., \& Hapidin, H. (2018). Pengaruh Bermain Peran Mikro terhadap Kecerdasan Interpersonal. Jurnal Obsesi : Jurnal Pendidikan Anak Usia Dini, 2(1), 34.

Datau, H. (2013). Keefektifan Metode Bermain Peran Terhadap Peningkatan Kemandirian Anak Usia Prasekolah Kelompok B Usia Lima Tahun di Pusat Paud Islam Terpadu Al-ishlah Kecamatan Kota Tengah Kota Gorontalo. Skripsi. Jurusan Bimbingan dan Konseling, Fakultas Ilmu Pendidikan, Universitas Negeri Gorontalo

Elisa, P. O. S., \& Hazizah, N. (2019). Penggunaan Metode Bermain Peran untuk Pengembangan Emosional Anak Usia Dini dalam Proses Pembelajaran. Fakultas Ilmu Pendidikan. Universitas Negeri Padang

Faridah, Fadillah, \& Halida. (2016). Peningkatan Perilaku Sopan Santun Pada Anak Usia 5-6 Tahun di Taman Kanak-Kanak PGRI Ketapang. Jurnal Pendidikan Dan Pembelajaran Khatulistiwa. Jurnal Pendidikan dan Pembelajaran Untan, 5(2).

Halifah, S. (2020). Pentingnya Bermain Peran Dalam Proses Pembelajaran Anak. JISIP (Jurnal Ilmu Sosial Dan Pendidikan), 4(3), 35-40.

Handayani, D. R. (2013). Penerapan Metode Bermain Peran untuk Meningkatkan Sikap Sopan Santun pada Anak Kelompok B di Paud TPQ Daarul Furqon Karanggeneng Boyolali Tahun Ajaran 2012/2013. Skripsi. Fakultas Keguruan dan Ilmu Pendidikan. Universitas Muhammadiyah Surakarta.

Hani, I. N. (2014). Peningkatan Pemahaman Siswa tentang Sopan Santun Melalui Pelatihan Role Playing. Laporan Penelitian. Program Studi Bimbingan Konseling Fakultas Keguruan dan Ilmu Pendidikan. Universitas Muhammadiyah Magelang.

Hasanah, Q. (2018). Peningkatan Karakter Sopan Santun melalui Kegiatan Bermain Peran (Role Playing) pada Anak Kelompok Bı di KB/TK An-Nur Malang. Skripsi. Program Studi Pendidikan Guru Pendidikan Anak Usia Dini. Universitas Negeri Malang. 
Hendryadi, H. (2017). Validitas Isi: Tahap Awal Pengembangan Kuesioner. Jurnal Riset Manajemen Dan Bisnis (JRMB) Fakultas Ekonomi UNIAT, 2(2), 169-178.

Masruroh, A., Dhieni, N., \& Karnadi, K. (2020). Pengaruh Metode Pembelajaran Bahasa Jawa Melalui Bermain Peran terhadap Perilaku Sopan Santun Anak. Indonesian Journal of Educational Counseling, 4(1).

Saifuddin, A. (2019). Penelitian Eksperimen dalam Psikologi. Jakarta : Prenadamedia Group

Seefeldt, C., Castle, S., \& Falconer, R. (2010). Social studies for the preschool/primary child ((8th ed.)). USA: Pearson.

Suryani, L. (2017). Upaya Meningkatkan Sopan Santun Berbicara dengan Teman Sebaya Melalui BImbingan Kelompok. E-Journal Mitra Pendidikan, o1(1).

Tomayahu. Sulastri. (2013). Pengaruh Bimbingan Kelompok Teknik Main Peran Terhadap Perilaku Sopan Santun Siswa Kelas VII Di MTs Al-Huda Kota Gorontalo. Skripsi. Jurusan Bimbingan dan Konseling Fakultas Ilmu Pendidikan. Universitas Negeri Gorontalo.

Vizeshfar, F., Dehghanrad, F., Magherei, M., \& Sobhani, S. M. J. (2016). Effects of Applying Role Playing Approach on Nursing Students 'Education. International Journal of Humanities and Cultural Studies, March, 1772-1781.

Wahyudi, D., \& Arsana, I. M. (2014). Peran Keluarga Dalam Membina Sopan Santun Anak Di Desa Galis Kecamatan Galis Kabupaten Pamekasan. Jurnal Kajian Moral Dan Kewarganegaraan, 1(2).

Yulianti, I., Isnani, A., Zakkiyyah, A. L., \& ... (2018). Penerapan bahasa jawa krama untuk membentuk karakter sopan santun di sekolah dasar. In Makalah. Prosiding Seminar Nasional di Universitas Muria Kudus: Kudus (Vol. 11, pp. 160-165).

Yus, A. (2011). Penilaian Perkembangan Anak Taman Kanak Kanak. Jakarta: Kencana Prenada Media Group. 